\title{
t)
}

\author{
超強力磁性材料を応用した振動変位の \\ アクティブ制御システム \\ ベレデ呉 進, 安田悦郎 \\ ヘルッ工業(株) 研究開発室 \\ （テ236-0004 神奈川県獚浜市金沢区福浦1-1-1 獚浜金沢ハイテクセンタテクノコア）
}

\section{The Active Attitude Control System by Using the Strongest Permanent Magnet}

\author{
Jin WU-BEREDER and Eturo YASUDA \\ $R \&$ D Laboratory, HERZ INDUSTRY CO., LTD. \\ Yokohama Kanazawa High-Tech Center, 1-1-1 Fukuura Kanazawa-ku Yokohama, Kanagawa 236-0004
}

(Received May 20, 1999)

\begin{abstract}
Using the world's strongest permanent magnet develops an active attitude control system. The system is designed for a wide variety of applications, which rely on pneumatic vibration isolation systems. Its applications range from precision laboratory environment to semiconductor manufacturing equipment, which demands the optimum noise performance and platform stability as well as to improve settling time and increase productivity.
\end{abstract}

Key Words: NEOMAX permanent magnet, Active attitude control system, Settling time, Control, Transmissibility

1.はじめに

近年, レーザーを用いた光学実験では, 光路長の長い実 験システムが数多く見受けられる。このため,使用される 空気ばね式防振台 (以下, 防振台という。)も大型になって きている．空気ばね式防振台が大型になると防振台を構 成する機器搭載ハニカムベンチの許容外の撓みの発生な ど,ベンチの剛性が問題となる。これに対する対処の仕方 は一般的には, 防振台の剛性を維持するために重くするが, 重くすると床の荷重制限によって設置できないことがお こる. 床の荷重制限内で防振台を分割して使用すること もあるが, それぞれの防振台は変位が一定にならず光軸が ずれる．レーザー光を直角または他の角度に光軸を曲げ て実験を行う場合も, 単一の防振台では対応できないこと もある，また，実験室の広さも限界がある，光路長が長い ために, 複数の実験室の壁にレーザー光を通す穴をあけて いる実験を行っている研究所もある.レーザー光の発光 部と受光部及び光学部品を設置した中間に小型の非防振 または防振ゴムを使用した簡易防振の光学ベンチを使用 することが多い.やむを得ず非防振のベンチを使用して いる研究者が多いが, レーザーを用いた光学実験を遂行す る上で分割された防振台が求められている.

現状の空気ばね式防振台に装着されているメカニカル オートレベルセンサの不感帯は $0.5 \mathrm{~mm}$ から $1 \mathrm{~mm} に$ 設定され ており, 機器搭載用ベンチの姿勢位置制御を高精度に行う
ことができない. 複数の小さな空気ばね式防振台を使用 する上で, それぞれの3次元空間における相対姿勢位置を許 容精度範囲内に制御できれば空気ばね式防振台が持つ問 題は解決する. 本稿では, この問題を解決するために筆者 らが開発したアクティブ姿勢制御システムについて述べ る。

\section{2. アクティブ姿勢制御システムの構成}

従来の空気ばね式防振台にFig.1に示す姿勢制御システ ムを追加し, 複数台のベンチの相対姿勢をアクティブに制 御することを可能とするシステム開発を行った.

開発にあたって次の3点に留意した. (1)ベンチを支持す る空気ばね周辺に変位センサ及びアクチュエータを取り

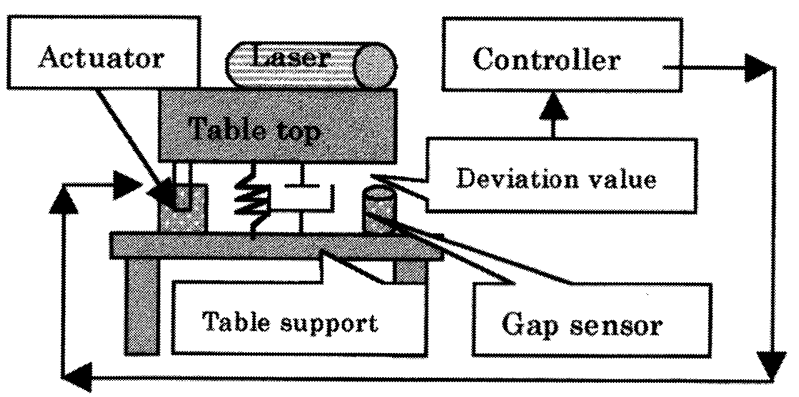

Fig.1 The structure of active attitude control system. 
付け,ベンチの姿勢位置を常に制御開始時の初期位置と一 致するようシステムを制御する。(2)高精度な防振性能を 損なわず,複数のベンチの相対姿勢位置を制御するために はFig.2に示す防振域外の周波数域でベンチの姿勢位置を 制御しなければならない1)。(3)防振域内では相対姿勢位置 制御は防振制御の相互干渉になり兼ねず, 避けなければな らない.このような場合は,ローパスフィル夕を制御回路 に組み込むことが一般的だが, 期待する効果が不充分であ り, 高周波低応答性の電磁式アクチュエータ4)を開発す る.

\section{3. アクチュエータの原理及び構成}

一般的に, 空気ばね式防振台の機器搭載荷重は数キロか ら数トンまである．特に大荷重の場合は大きな推力が必 要となる. 今回超強力磁性材料のNEOMAX磁石 (Nd-Fe-B Magnet）を応用し電磁アクチュエータを製作してみること にした. NEOMAX磁石の特性はサマリウムコバルト磁石 に比べ, 最大エネルギー積 $(B H)_{\max }$ は量産レベルで約 374 $\mathrm{kJ} / \mathrm{m}^{3}$ とはるかに性能が高い。しかも比重は約 $7.5 \mathrm{~g} / \mathrm{cm}^{3}$ で, サマリウムコバルト磁石より $10 \%$ 以上軽く,電磁アクチュ エー夕に求められた大出力, 小型, 軽量化が可能となった.

三次元空間において姿勢を制御する場合, 使用するアク チュエータもできるだけ各軸方向において自由度を持っ ていなければならない。また, NEOMAX磁石は上述の非常 に優れた性能を持っていると同時に残留磁束密度 $(B r)$ 及び 保磁力 $(i H c)$ の温度係数が大きいため, 使用温度に配慮しな ければならない。これらを考慮してFig.3に示す磁石とコ イルの非接触式の基本構造を持つ電磁式アクチュエータ3) を開発した。

電磁式アクチュエータは磁気と電流の間に働く力を利 用したものである。静的な場合, 電磁力 $\Delta F$ は下の式で求め られる21.

$$
\Delta F=B I \Delta L \sin \theta[\mathrm{N}]
$$

ただし $\Delta L(\mathrm{~m})$ は導体の長さ, $B(\mathrm{~T})$ はその点の磁束密度, $I$ (A) は導体に流れている電流, $\theta$ は電流と磁束のなす角であ る.

実際の応用において, 導体は均一磁界中に置かれて, 電 流と磁束のなす角は $90^{\circ}$ である，導体に受ける全体の電磁

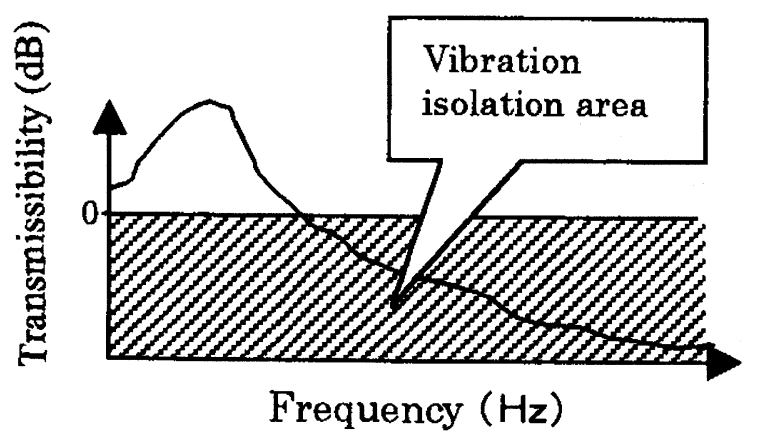

Fig.2 An example transmissibility of pneumatic vibration isolation systems.
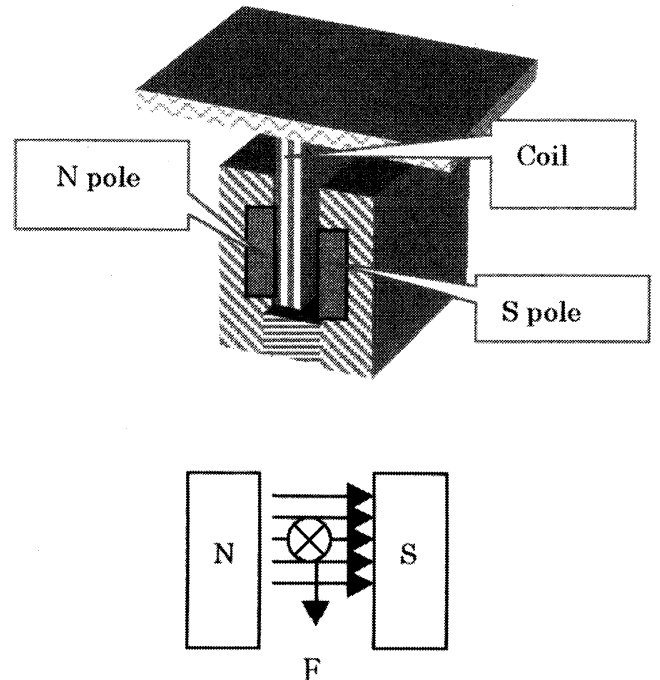

Fig.3 Basic components of electromagnetic actuator.

力Fは

$$
F=n B I L[\mathrm{~N}]
$$

で計算することができる，たたし,$n$ は導体の本数である.

Fig.3の導体は実用上はFig.4のようにコイルの形状に作 られている. コイルの巻き数 $N$, 抵抗は $R$, 自己インダク夕 ンスはLとする。

$$
L=\frac{N \cdot \phi}{I}
$$

一般に,上記コイルのL/Rの大小 (Fig.5 (a))によって周波数 応答特性(Fig.5 (b))が分かる. コイルのL/R值を適切に設 定することによって推力の周波数特性が求められる.

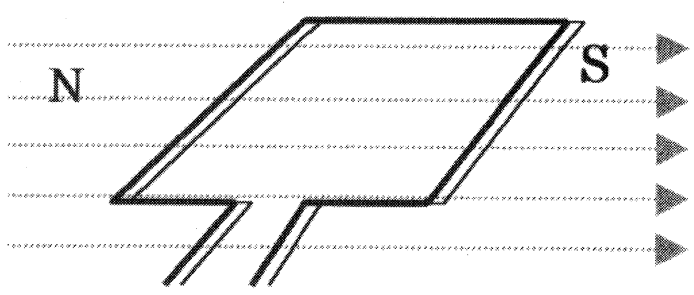

Fig.4 The coil of electromagnetic actuator.
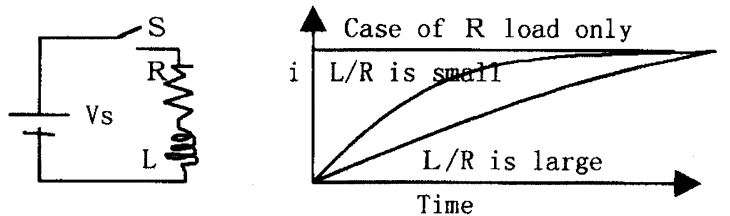

(a)

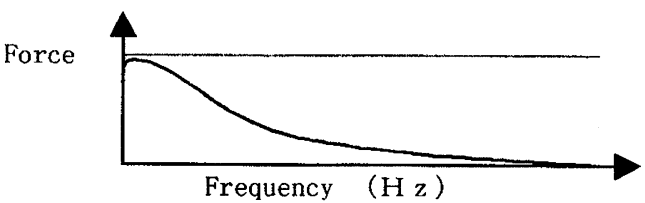

(b)

Fig.5 (a) L/R characteristics of coil and (b) frequency response. 


\section{4. アクチュエータに関する実験}

アクチュエータの磁石側の磁束密度を実際に測定して みた。 Fig.6はアクチュエータ取付けの一例である. Fig.7 は垂直用アクチュエータに用いた磁石の磁束密度分布状 況の実測等高線図である。

Fig.7は, アクチュエータのN/S極の2枚の磁石の中間位置 でプローブを固定し, 被測定磁石の平面内でアクチュエー 夕を動かしながら, 磁束密度を測定したものである。Fig.8 は電流の流れる方向に直交する実測磁束密度の分布值を 積分し, 上記の式(1.2)により推力を算出したものである.

\section{5. 振動変位のアクティブ制御システム}

制御の流れは, ギャップセンサからの值を $\mathrm{A} / \mathrm{D}$ 変換後 CPUに送る $\rightarrow$ 初期值と比較し, その偏差值を制御偏差量と して処理 $\rightarrow$ 適切な指令を電磁アクチュエータのドライ バーへ送るーアクチュエータ駆動, となる(Fig.1参照5) $)$.

実際のシステムにおいて, 変位の制御は2段階に分けられ

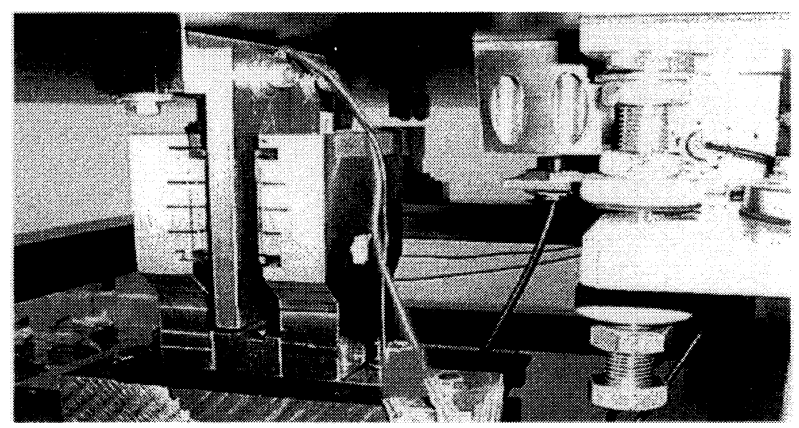

Fig.6 Actual electromagnet actuator.

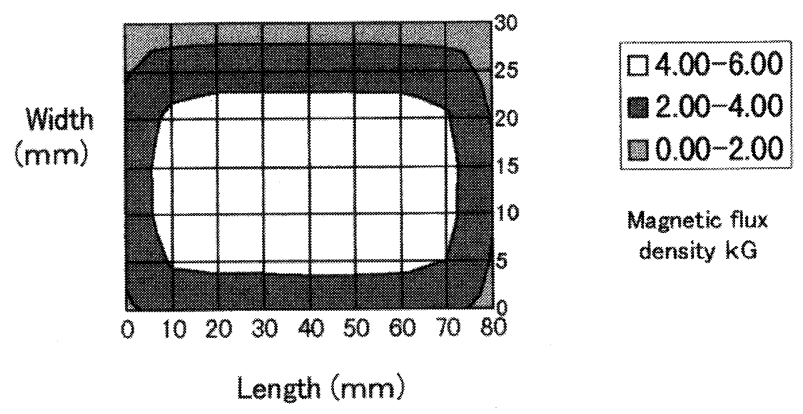

Fig.7 Distribution of magnetic flux density.

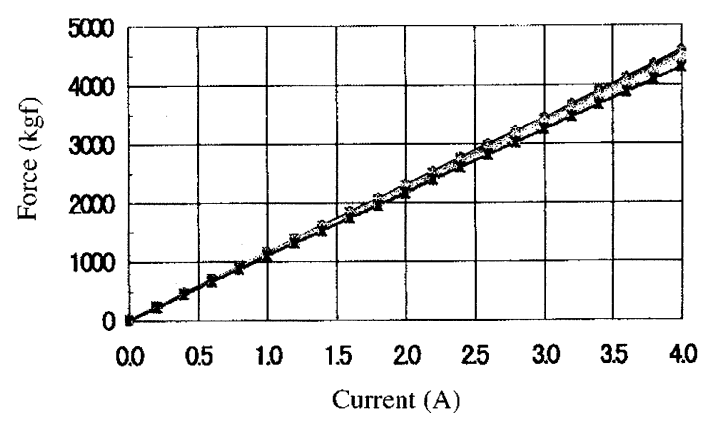

Fig. 8 The force of the electromagnetic actuator.
る. 前半で述べたように, この振動変位制御システムは通 常のメカニカルレベルセンサ/バルブ及びギャップセンサ を同時に使用している。そのため, 変位が発生した場合に メカニカルレベルセンサが振動変位を感知し, 空気ばね内 の圧力を調整することによって変位を復帰させる．同時 にギャップセンサもこの振動変位をキャッチし, 一連の処 理を経て,アクチュエータにより振動変位をキャンセルす る.しかしメカニカルレベルセンサ/バルブとギャップセ ンサ/アクチュエータの動きは同期しないため, 変位キャン セルに沶いて抵触現象が起きる。この問題を解決するた めに, 変位制御を“粗”制御と“精密”制御の2段階に分けた.

振動変位が発生した場合, メカニカルレベルセンサの不 感帯を超えた場合, まずメカニカルレベルセンサバルブに よる空気圧の調整で変位を不感帯内まで復帰させる. 次 にギャップセンサ/アクチュエータのアクティブ制御シス テムにより変位をさらに $2 \mu \mathrm{m}$ 以内に復帚させる.

このように試作した振動変位のアクティブ制御システ ムで実測した結果をFig.9, Fig.10, Fig.11, Fig.12に示す。

Fig.9, Fig.10は, それぞればね上荷重 $400 \mathrm{~kg}$ の時の掃引加 振による周波数軸の变位応答值である. 制御時と非制御 時の变位の動的変化の差が著しい. 垂直, 水平方向の共振 点付近における共振倍率が低下していることが確認でき た。

Fig.11は200mmの高さから重さ250gの重りを自由落下さ せた時のアクティブ制御システムのインパルス応答を示 す。アクティブ制御システムのインパルス減衰は明らか に早く,かつ変位の復帰精度も良いことが分かる。

Fig.12は, ばね上搭載重量 $440 \mathrm{~kg}$ の時, 防振台ベンチの端

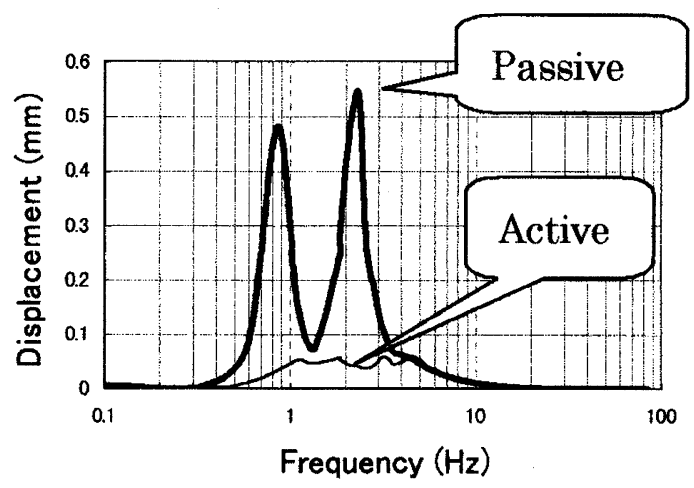

Fig.9 Displacement responses of passive and active attitude control systems (vertical direction).

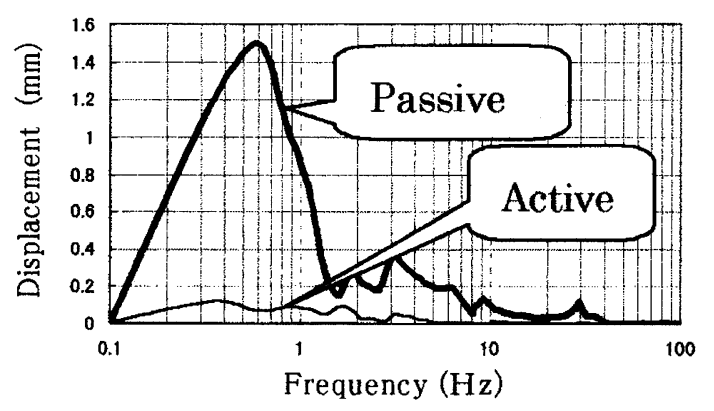

Fig.10 Displacement responses of passive and active attitude control systems (horizontal direction). 


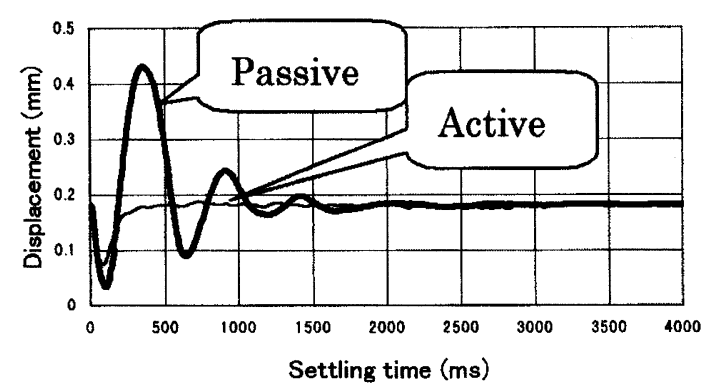

Fig.11 Impulse responses of passive and active attitude control systems.

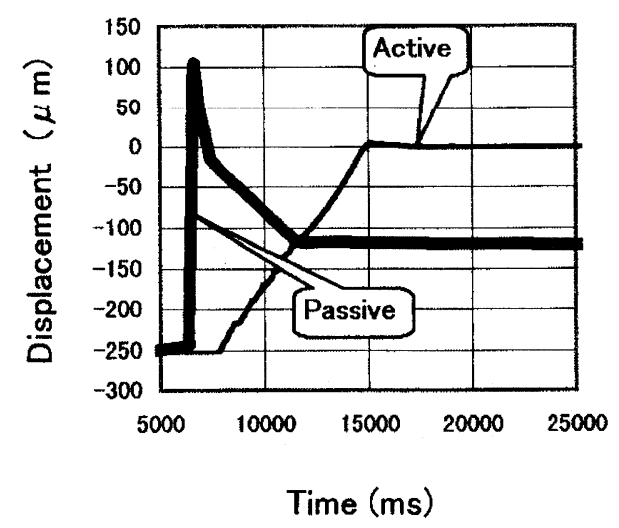

Fig.12 Comparison of return accuracy of passive and active attitude control systems.

に6kgの重りを載せた後の復帰精度実験における実測值で ある. 空気ばね式防振台の変位の復帰は土0.5 1mm範囲 内にランダム性があるが,この実験における復帰精度は約 $120 \mu \mathrm{m}$ とっているのに対して, 振動変位アクティブ制御 システムによる復帰精度は土 $2 \mu \mathrm{m}$ 以内になっており,さら に繰り返し実験によって再現性も確認されている。

Fig.13は, 振動変位のアクティブ制御システムを示す.

\section{6. 結 論}

超強力磁性材NEOMAX磁石を応用した電磁式アクチュ

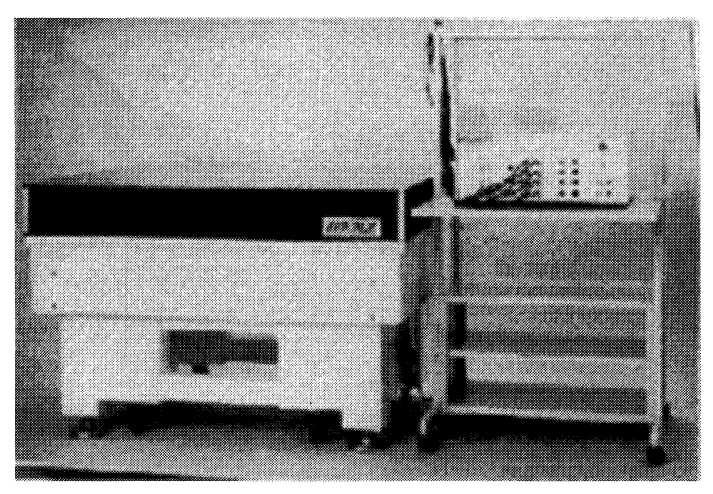

Fig.13 General view of the active attitude control system.

エータは振動変位アクティブ制御システムにおいて $20 \mathrm{~Hz}$ 前後までの応答性が期待でき, 極低周波域において共振倍 率の高い空気式防振台のアクティブ制御用に適している ことが明らかとなった．振動変位アクティブ制御システ ムの変位制御の保持精度を土 $2 \mu \mathrm{m}$ 内に抑えることが出来 た.

\section{謝 辞}

本研究の基礎技術開発は, 神奈川県からの助成金, 本研 究は横浜市ならびに(財)横浜産業振興公社からの知的所有 権担保による開発資金融資により行われたものであり, 関 係機関の皆様に謝意を表します。

\section{参考文献}

1）崔衛民, 金光 陽一, 野波 健蔵, 渡辺 和英：機械学会論文集 60575C (1994) 2227

2) 武藤 高義：アクチュエータの駆動と制御 (1995,コロナ社).

3）岡田養二,長坂長彦: サーボアクチュエータとその制御 (1996, コロナ社).

4）日本工業技術振興協会固体アクチュエー夕研究部会：精密制 御用アクチュエータ便覧, フジテクシステム (1994).

5) 堀 康郎, 荻原 修哉, 藤澤二三夫, 中村 満 : 機械学会論文集 63613C (1997) 2996.

$$
\text { レーザーワード }
$$

\section{アクティブ姿勢制御システム}

\section{(active attitude control system)}

空気ばね式防振システムは機器搭載用ベンチ, 空気ばね, 防振架台より構成される。また搭載機器の形状や重量分 布及び振動によって, 架台に対して空気ばねによって支持 された機器搭載用ベンチは傾くが,この傾きはメカニカル レベルセンサーによってエアの給排気を行わせ,エアータ ンクの空気圧を調整することによって一定の水平位置を 保つ構造になっている.しかしこのようなメカニカルレ
ベルセンサーによる水平調整の得られる精度は通常士 $1 \mathrm{~mm}$ 程度しか得られず,かつ高さ方向に限る。

Active Attitude Controlは従来の空気ばね式防振システム における機器搭載用ベンチを初期に設定した位置を目標 位置として変位センサーとアクチュエータ及び制御部を 用いて3次元空間に打いて制御するシステムである。制御 精度は $2 \mu \mathrm{m}$ である。

(ベレデ呉進) 